\title{
PEREMPUAN DALAM CERITA CALON ARANG KARYA PRAMOEDYA ANANTA TOER PERSPEKTIF FEMINIS SASTRA
}

\author{
Valentina Edellwiz Edwar ${ }^{1}$, Sarwit Sarwono ${ }^{2}$, dan Yayah Chanafiah \\ ${ }^{1,2,3}$ Program Studi Pendidikan Bahasa dan Sastra Indonesia \\ Jurusan Pendidikan Bahasa dan Seni \\ FKIP Universitas Bengkulu \\ valentinaedell@gmail.com
}

\begin{abstract}
Abstrak
Tujuan penelitian untuk mendeskripsikan dominasi patriarki terhadap perempuan dan sikap serta keputusan perempuan atas dominasi patriarki yang dialaminya dalam Cerita Calon Arang (CCA) karya Pramoedya Ananta Toer. Metode yang digunakan adalah analisis isi atau konten. Teknik pengumpulan data dalam penelitian ini adalah teknik dokumentasi. Teknik analisis data penelitian ini adalah analisis isi. Hasil penelitian menunjukkan bentuk-bentuk dominasi patriarki dalam CCA dapat dilihat dari tiga bagian, yakni (1) Status sosial perempuan dalam masyarakat, (2) Kondisi inferior perempuan, (3) Relasi perempuan dan laki-laki dalam CCA. Adapun, sikap-sikap perempuan terkait dominasi yang dialaminya dilihat dari gugatan perempuan. Status sosial, kondisi inferior, dan relasi masing-masing perempuan dengan tokoh lain di dalam CCA telah membentuk sikap-sikap yang berbeda. Sikap masing-masing perempuan dalam CCA dengan kedudukannya telah menyebabkan gugatan yang dilakukan berbeda-beda pula. Calon Arang sebagai tokoh utama dalam CCA telah menjadi ikon yang menggugat masyarakat dan pihak kerajaan atas kondisi inferior yang dialaminya. Lain halnya dengan Ratna Manggali yang mewakili perempuan dengan penerimaannya atas status dan kondisinya di dalam masyarakat. Gugatan lain juga ditunjukkan oleh Wedawati yang memilih untuk tidak menikah dan menjadi pertapa perempuan. Selanjutnya adalah sikap yang ditunjukkan oleh tokoh Ibu Tiri Wedawati yang turut melanggengkan kondisi inferior perempuan dengan mengamankan posisinya dalam keluarga. Kesimpulan dari penelitian adalah bahwa CCA banyak menunjukkan peristiwaperistiwa yang dapat dianalisis dengan perspektif feminis sastra terkait dengan kedudukan dan peran perempuan dalam karya sastra.
\end{abstract}

\section{Kata kunci: Kedudukan perempuan, dominasi patriarki, feminis sastra, cerita Calon Arang karya Pramoedya Ananta Toer.}

\begin{abstract}
This research was aimed to describe patriarchy domination faced by women and women's attitude as well as decision toward the patriarchy domination in Story of Calon Arang by Pramoedya Ananta Toer. Method used in this research was content analysis. Data collection technique in this research was documentation technique. Technique of data analysis in this was content analysis. The results of this research showed that forms of patriarchy domination in Story of Calon Arang could be seen in three parts, which were (1) Women's social status in society, (2) Inferior condition of women, (3) Relation between women and men in Story of Calon Arang. As for, women's attitude related to the domination was reflected by their criticism. Social status, inferior condition, and relation of each woman with other characters in Story of Calon Arang had built their characters. The attitude of
\end{abstract}


women in CCA toward their ranks had caused criticism which was done in different ways. Calon Arang as the main character have become an icon who criticized society and part of the kingdom for inferior condition he struggled with. Different thing happened with Ratna Manggali who represents women with her approval over her status and condition in society. Another criticism was shown by Wedawati who chose not to marry and become female hermit. Tle last one was the attitude shown by Wedawati's stepmother who preserved inferior condition of women by securing her position in family. The conclusion of this research was that Story of Calon Arang showed many events to be analyzed with feminist perspective of literature related to the rank and role of women in literary work.

Keyword: Women ranks, patriarchy domination, feminist perspective of literature, story of Calon Arang by Pramoedya Ananta Toer.

\section{PENDAHULUAN}

Novel merupakan karya sastra yang lahir dari kondisi sosial, budaya, ekonomi, dan politik pada zamannya. Selain mencerminkan kondisi masyarakat, novel juga mengusung gagasan atau ideologi penulis. Lewat novel para pembaca mampu mengetahui bagaimana kondisi suatu masyarakat beserta peristiwaperistiwa di dalamnya.

Cerita Calon Arang (selanjutnya akan disingkat (CA) salah satu dari sekian novel yang menggambarkan kondisi masyarakat pada zamannya. Novel ini ditulis oleh Pramoedya Ananta Toer yang diyakini sebagai maestro sastra Indonesia. Sebagaimana karya Pram pada umumnya, dalam CCA Pram menghadirkan beberapa tokoh perempuan yang berperan penting di tiap peristiwa.

CCA berkisah tentang seorang janda tua yang berprofesi sebagai tukang teluh di Dusun Girah. Calon Arang merupakan janda dengan satu orang anak perempuan kesayangan yang amat cantik berumur di atas 25 tahun dan belum menikah yakni, Ratna Manggali. Masyarakat sekitar mulai memperbincangkan Ratna Manggali yang belum juga menikah. Perbincangan pun terus berlanjut hingga sampai ke telinga Calon Arang. Mengetahui anak perempuannya menjadi bahan perbincangan marahlah Calon Arang terhadap orang-orang dusun sekitarnya.
Akhirnya Calon Arang menyebar teluh sehingga ratusan orang meninggal.

Peristiwa ini sampai kepada Raja Erlangga yang akhirnya memerintahkan balatentara untuk menangkap Calon Arang dalam kondisi hidup atau mati. Namun, balatentara berhasil dikalahkan oleh Calon Arang dengan kekuatannya. Akhirnya Raja meminta bantuan pendeta yakni Empu Baradah. Berkat operasi terpadu yang dipimpin Empu Baradah maka Calon Arang dapat dikalahkan.

Pembacaan selintas terhadap CCA akan menimbulkan pernyataan bahwa apa yang dilakukan tokoh utama perempuan di dalamnya adalah sebuah bentuk kejahatan yang sadis. Selain itu, tokoh-tokoh perempuan lain seolah tidak memiliki andil apa-apa dalam cerita. Namun, jika CCA dicermati sedemikian rupa dan menggunakan ilmu sastra sebagai alat yang objektif untuk melihat akar permasalahan dalam CCA, maka pembaca akan melihat sesuatu yang berbeda.

CCA dilihat dengan perspektif feminis sastra yang didasarkan pada inferioritas perempuan (Kutha Ratna, 2009:192) dan sebagai upaya pemahaman kedudukan dan peran perempuan dalam karya sastra (Endraswara, 2008: 146), maka yang sesungguhnya terjadi adalah sikap dan keputusan tokoh-tokoh perempuan terhadap budaya patriarki. 
Pada masyarakat patriarki tolak ukur seluruh ruang-ruang di masyarakat adalah laki-laki, namun perlu diingat bahwa perempuan juga menjadi bagian dari masyarakat tersebut sehingga perempuan memiliki peluang yang sama untuk melanggengkan budaya patriarki dengan pandangan dan sikap mereka.

Sementara itu, perbedaan kedudukan perempuan satu dengan perempuan yang lain dalam CCA turut menentukan sikap dan peran perempuan dalam masyarakat patriarki. CCA sebagai novel yang menampilkan kondisi masyarakat pada zamannya menunjukkan bagaimana kedudukan masing-masing perempuan di dalam cerita mempengaruhi sikap-sikap perempuan dalam masyarakat patriarki yang ditunjukkan lewat keputusan-keputusan perempuan atas pilihan mereka.

Dari hasil analisis awal penulis, tokoh perempuan dalam CCA menghadapi suatu kondisi yang sama yakni dominasi budaya patriarki. Oleh karena itu penulis tertarik melakukan penelitian lebih lanjut terhadap novel Cerita Calon Arang karangan Pramoedya Ananta Toer dengan judul Perempuan dalam Novel Cerita Calon Arang Karya Pramoedya Ananta Toer Perspektif Feminis sastra.

Peneltiian ini bertujuan untuk mendeskripsikan bentuk dominasi budaya patriarki yang dialami perempuan dan sikap serta keputusan yang diambil perempuan terkait perlakuan dominasi patriarki yang dialaminya.

\section{Perspektif Feminis Sastra}

Feminisme ialah teori tentang persamaan antara laki-laki dan perempuan di bidang politik, ekonomi, sosial; atau kegiatan terorganisasi yang memperjuangkan hak-hak serta kepentingan perempuan, Goefe dalam (Suharto \& Sugihastuti, 2015). Ada banyak jenis feminisme. Namun secara umum, ada empat jenis feminis, yakni liberal, radikal, marxis, dan sosialis.

Munculnya gerakan feminis diakibatkan oleh adanya ketimpangan yang dialami antara laki-laki dan perempuan. Ketimpangan itu menguntungkan salah satu pihak dan merugikan pihak lainnya, satu pihak mendominasi pihak lainnya. Sehingga muncul berbagai kajian mengenai penyebab ketimpangan-ketimpangan tersebut. Salah satunya adalah patriarki.

Pada awalnya definisi patriarki hanya sebatas garis keturunan ayah atau aturan laki-laki tertua dominan dalam struktur kekeluargaan tradisonal (Thornman, 2010:67). Namun kemudian Kate Millet dengan karyanya Sexual Politics mempopulerkan politik seksual dan meluaskan definisi patriarki.

Patriarki menjadi bermakna penindasan terinstitusionalisasi terhadap semua perempuan yang dilakukan oleh laki-laki. Selanjutnya Millet (Thornman, 2010:67) mengatakan bahwa patriarki adalah institusi politik, yakni institusi yang separuh populasinya adalah perempuan, dikendalikan oleh separuhnya yang merupakan laki-laki, dan jenis kelamin adalah 'kategori status dengan berbagai implikasi politik'. Penekanan atas aspek budaya dan ideologis sebagai sarana utama patriarki memegang 'kontrol yang kejam, total, dan seolah-olah tidak dapat dibantah'. Millet dalam Sexual Politics menyatakan bahwa penyelesaian masalah tersebut adalah dengan adanya revolusi budaya.

Patriarki menurut Allen (Hellwing, 2003:1) adalah berbagai sistem sosial ekonomi dan budaya yang melembaga, dan karenanya mengabadikan kekuasaan hegemonik kaum laki-laki yang bersifat eksklusif. Hal tersebut berarti bahwa posisi perempuan dibatasi dan takluk, yang antara lain berakibat pada penggambaran perempuan sebagai sosok inferior secara sosial (Hellwing, 2003:1). Artinya dalam 
masyarakat yang menganut budaya patriaki, laki-laki memegang kontrol dalam segala bidang.

$$
\text { Ketika suatu masyarakat }
$$

melanggengkan sistem patriaki dalam

budayanya maka perempuan akan selalu menjadi kelas dua atau inferior, tersubordinasi yang dominasi oleh laki-laki. Sebagaimana Wollstonecraft menyebut bahwa penindasan perempuan bersifat budaya (dibangun dan dijalani dalam pelbagai praktik dan teks budaya), sosial (diafirmasikan lewat institusi-institusi sosial, terutama pernikahan) dan politik (ditegakkan lewat perundang-undangan), dan semuanya diwujudkan (Thornman, 2010:23). Dalam budaya patriarki perempuan tidak mendapatkan ruangruang yang sama dengan laki-laki, baik dalam ruang domestik maupun publik karena semua ruang didominasi oleh lakilaki.

Akibat dominasi tersebut akhirnya muncul berbagai gerakan dan perlawanan. Gerakan yang mengusung dan menuntut persamaan hak, kebebasan, dan kesetaraan, yakni feminisme.

Namun, gerakan feminisme bukanlah sebuah upaya pemberontakan perempuan terhadap laki-laki, atau upaya melawan pranata sosial, maupun upaya untuk mengingkari kodrat perempuan melainkan merupakan upaya untuk mengakhiri penindasan dan eksploitasi perempuan. Feminis merupakan perjuangan dalam rangka mentransformasikan sistem dan struktur sosial yang tidak adil menjadi keadilan bagi laki-laki dan perempuan, Fakih dalam (Sugihastuti dan Suharto, 2015:63).

Kaitan feminis dalam sastra adalah bahwa karya merupakan salah satu wujud dari ideologi patriarki, Millet (Thornman, 2010: 70). Dalam teks-teks sastra, perempuan ditampilkan sebagai kelas kedua yang didominasi oleh kelas lainnya, yakni laki-laki. Lewat teks-teks sastra yang dihegemoni oleh budaya patriarki, hubungan antara perempuan dan laki-laki ditampilkan dalam keadaan timpang yang kemudian membentuk kelas-kelas yang tidak setara atau munculnya subordinat. Ketimpangan antara perempuan dan lakilaki dalam teks-teks sastra itulah menjadi tugas bagi feminis sastra untuk mencari tahu apa saja yang menjadi pemicu ketimpangan tersebut, bagaimana perempuan dinarasikan, dan bagaimana peran tokoh perempuan tersebut di dalam karya sastra.

Kajian feminis sastra sedapat mungkin harus berhubungan dengan halhal berikut:

1) Mengungkap karya-karya penulis wanita masa lampau dan masa kini agar jelas citra perempuan yang merasa ditekan oleh tradisi. Dominasi patriaki harus terungkap secara jelas dalam analisis.

2) Mengungkap berbagai tekanan para tokoh perempuan dalam karya sastra yang ditulis pengarang laki-laki.

3) Mengungkap ideologi pengarang wanita dan pria, bagaimana mereka memandang diri sendiri dalam kehidupan nyata.

4) Mengkaji dari asek ginokritik, yakni memahami bagaimana proses kreatif kaum feminis. Apakah penulis perempuan memiliki kekhasan dalam gaya dan ekspresi atau tidak.

Artinya kajian feminis sastra harus mampu mengungkap aspek-aspek ketertindasan perempuan dalam karya sastra sekecilkecilnya (Endraswara, 2008:147). Kemudian bagaimana perilaku perempuan dalam menghadapi ketidakadilan gender yang berakar dari sistem patriarki yang ada di masyarakat. Pada akhirnya kajian feminis sastra dengan argumen yang cermat serta dokumentasi yang saksama dapat mempengaruhi pembaca dari kedua belah pihak, yakni perempuan dan laki-laki, 
untuk mengubah politik seksual yang direpresentasikan oleh karya-karya yang ditelitinya, Gilbert dan Gubar (Sugihastuti dan Suharto, 2015:72).

\section{Perempuan dalam Karya Sastra}

Penelitian sastra berspektif feminis memfokuskan penelitian pada tokoh perempuan dalam karya sastra, yakni bagaimana posisi atau kedudukan perempuan di dalam teks-teks sastra tersebut. Sastra diharapkan menjadi salah satu pintu bagi gerakan untuk menyebarkan paham-paham feminis lewat tokoh-tokohnnya.

Tokoh merupakan elemen struktural fiksi yang melahirkan peristiwa Sayuti, 2000:73). Ditinjau dari segi keterlibatannya dalam keseluruhan cerita, tokoh dibedakan menjadi dua jenis, yakni tokoh sentral dan tokoh periferal. dalam (Suharto \& Sugihastuti, 2015:50).

CCA menampilkan empat tokoh perempuan yang menghadapi permasalahan yang sama, yakni hidup dalam dominasi budaya patriarki. Tetapi kemudian, perempuan-perempuan ini mengambil perannya masing-masing dalam jalannya peristiwa. Pengambilan masing-masing peran oleh perempuan ini kemudian menimbulkan perbedaanperbedaan terkait dengan bagaimana mereka menyikapi dominasi patriarki yang ada.

Perbedaan empat tokoh perempuan di CCA dalam menyikapi dominasi patriarki menunjukkan bagaimana sikap dan kedudukan atau posisi mereka dalam karya sastra, hal itu sejalan dengan tujuan penelitian sastra berspektif feminis.

\section{METODE}

Metode yang digunakan dalam penelitian adalah penelitian kualitatif, yakni penelitian yang bermaksud untuk memahami fenomena tentang apa yang dialami subjek penelitian misalnya perilaku, persepsi, motivasi, tindakan, dan lain-lain. Secara holistik dan dengan cara deskripsi dalam bentuk kata-kata dan bahasa (Moleong, 2007:6). Penelitian kualitatif lebih sesuai dengan hal-hal yang bersangkutpaut dengan masalah kultur dan nilai-nilai, seperti sastra (Semi, 2012:34).

Penelitian ini juga menggunakan metode analisis isi atau analisis konten. Analisis isi adalah strategi untuk menangkap pesan karya sastra. Penelitian analisis isi dalam karya sastra didasarkan pada kenyataan bahwa penulis ingin menyampaikan pesan secara tersembunyi kepada pembaca sehingga pesan tersebut harus dilacak (Endraswara, 2008:161).

Isi dalam metode analisis isi terdiri atas dua macam, yaitu isi laten dan isi komunikasi. Isi laten adalah isi yang terkandung dalam dokumen dan naskah, sedangkan isi komunikasi adalah isi yang terkandung sebagai akibat komunikasi yang terjadi (Kutha Ratna, 2009:48). Penelitian menggunakan metode analisis isi menekankan bagaimana memaknakan isi komunikasi, memaknakan isi interaksi simbolik yang terjadi dalam peristiwa komunikasi.

Data dalam penelitian yakni peristiwaperistiwa yang ada di dalam novel. Sumber data dalam penelitan ini adalah novel Cerita Calon Arang karya Pramoedya Ananta Toer.

Penulis mengkaji novel Cerita Calon Arang menggunakan pendekatan feminis sastra. Ada banyak pendekatan dan teori dalam feminis sastra, dalam penelitian ini penulis menggunakan pendekatan yang mengacu pada teori feminis Marry Woolstonecraft yang menyebutkan bahwa penindasan perempuan bersifat budaya (dibangun dan dijalani dalam pelbagai praktik dan teks budaya), sosial (diafirmasikan lewat institusi-institusi sosial, terutama pernikahan) dan politik 
(ditegakkan lewat perundang-undangan), dan semuanya diwujudkan (Thornman, 2010)

Data dalam penelitian ini dikumpulkan dari telaah isi novel, penulis juga menggunakan dokumen-dokumen lain yang relevan dengan penelitian ini.

Adapun langkah-langkah analisis data pada penelitian ini sebagai berikut:

1. Membaca novel Cerita Calon Arang secara cermat dan berulang-ulang serta menandai peristiwa-peristiwa dalam cerita CCA yang berkaitan dengan penelitian.

2. Mencatat data yang berupa peristiwa-peristiwa dari isi teks. Isi teks terdiri dari isi tersurat maupun isi tersirat yang menunjukkan makna teks. Dalam penelitian ini peristiwa yang mengacu pada bentuk budaya patriarki dan peristiwa-peristiwa terkait bagaimana interaksi tokoh perempuan menghadapi budaya patriaki tersebut.

3. Mengklasifikasikan data atau isi teks dan dikategorikan sesuai dengan acuan penelitian, yakni peristiwia-peristiwa yang merujuk pada bentuk-bentuk budaya patriarki terhadap perempuan dan bagaimana interaksi tokoh perempuan menghadapi bentuk budaya patriarki tersebut.

4. Menganalisis data. Menganalisis peristiwa-peristiwa yang telah diklasifikasikan baik bentuk budaya patriarki maupun bagaimana tokoh perempuan menghadapi bentuk budaya patriarki perempuan dalam bentuk dekripstif.

5. Menarik kesimpulan. Menyimpulkan dari hasil memaknakan teks dalam bentuk deskriptif. Pada bagian ini, penulis menarik kesimpulan dari hasil analisis yang telah dilakukan ketika memaknai peristiwa-peristiwa yang ada dalam CCA.

\section{HASIL DAN PEMBAHASAN}

Berdasarkan hasil analisis bentuk dominasi budaya patriarki serta sikap dan keputusan perempuan atas perlakuan dominasi yang dialaminya, ditemukan hasil sebagai berikut:

\section{Bentuk Dominasi Budaya Patriarki yang Dialami Perempuan dalam CCA.}

Hasil temuan yang didapatkan selama penelitian, bentuk dominasi budaya patriarki yang dialami perempuan dalam CCA dapat dilihat dari tiga bagian, yakni:

1) Status sosial perempuan dalam masyarakat. Status sosial perempuan dalam masyarakat dalam CCA meliputi, perempuan sebagai janda, perpuan yang belum menikah, anak perempuan, dan perempuan sebagai ibu tiri.

2) Kondisi inferior perempuan. Kondisi inferior perempuan dalam CCA terlihat dari perbedaan status dan kemampuan perempuan dan lakilaki. perbedaan pandangan masyarakat patriarki dalam bidang pekerjaan, perbedaan mengebai pernikahan, dan pelabelan terhadap perempuan (perawan tua).

3) Relasi antara perempuan dan lakilaki dalam CCA. Ditemukan beberapa jenis relasi antara perempuan dan laki-laki dalam CCA, yakni relasi langsung, tidak langsung, dan tersembunyi.

\footnotetext{
Perempuan-perempuan yang Menggugat

Pada bagian ini dibahasa apa saja gugatan yang diperjuangkan perempuan dan bagaimana sikap serta keputusan perempuan atas dominasi patriarki yang dialaminya.
} 
dalam CCA:

Gugatan-gugatan perempuan

1) Hak persamaan perempuan dan laki-laki

2) Hak mengenai pekerjaan

3) Hak mengenai pernikahan

4) Hak memutuskan pilihan hidup Gugatan tersebut ditunjukan dari berbagai peristiwa yang dialami perempuan dalam CCA. Calon Arang menggugat masyarakat dan pihak kerajaan dengan cara menyebarkan teluh ke seluruh penduduk Desa Girah. Wedawati memutuskan untuk tidak menikah dan menjadi pertapa perempuan. Selanjutnya ada pula tokoh perempuan yang secara sadar dan tidak sadar turut serta melanggengkan budaya patriarki, yakni Ratna Manggali dan Ibu Tiri Wedawati.

Ratna Manggali menerima semua perlakuan dominasi patriarki yang dialaminya. Baik ketika Ratna Manggali dilabeli sebagai perawan tua hingga la dinikahi dengan tujuan untuk mencari kelemahan dan mengalahkan ibu kandungnya. Terakhir ada lbu Tiri Wedawati yang secara sadar mengamankan posisinya dalam kelaurga dengan jalan mendominasi anak tirinya sendiri.

\section{PENUTUP}

\section{Kesimpulan}

Berdasarkan analisis yang telah dilakukan oleh penulis untuk menjawab rumusan masalah penelitian terhadap tokoh perempuan dalam Cerita Calon Arang (CCA) karya Pramoedya Ananta Toer, maka disimpulkan bahwa ada beberapa bentuk dominasi patriarki yang dialami perempuan dan bagaimana perempuan-perempuan tersebut menyikapi dominasi yang dialaminya.

Bentuk-bentuk dominasi patriarki yang dialami perempuan dalam CCA ditunjukkan dari berbagai peristiwa dalam cerita yang saling berkaitan. Pertama mengenai status sosial perempuan dalam masyarakat. CCA menghadirkan empat perempuan dengan status berbeda, yakni janda, perawan, anak tiri, serta istri kedua sekaligus ibu tiri. Status sosial perempuan dalam masyarakat menunjukkan siapa dan apa peran perempuan di lingkungannya.

Status sosial keempat tokoh perempuan dalam CCA menentukan bagaimana masyarakat sekitar memperlakukan perempuan-perempuan tersebut. Hal ini terkait dengan kondisi inferior yang dialami masing-masing perempuan dalam CCA. Dari hasil analisis temukan empat hal yang menyebabkan kondisi inferior pada perempuan, yakni perbedaan status dan kamampuan perempuan dan laki-laki, perbedaan pandangan masyarakat terhadap perempuan mengenai bidang pekerjaan, pandangan mengenai pernikahan, dan pelabelan terhadap perempuan (perawan tua).

Status janda merupakan kedudukan dan keadaan Calon Arang dalam masyarakat. Status janda tidak menguntungkan Calon Arang. la harus berhadapan dengan pandangan perempuan sebagai inferior/subordinat, lemah, dan tak memiliki kemampuan apapun. Selain itu, status janda menghadapkannya dengan kenyataan bahwa hidup harus terus berlanjut betapapun sulitnya keadaan. Maka dengan penuh sadar diri Calon Arang memilih bekerja sebagai tukang teluh demi memenuhi kebutuhan materil dan moril bagi dirinya dan anaknya. Namun lagi-lagi Calon Arang dan anak perempuannya berada pada posisi yang dirugikan dengan pekerjaannya. Tak ada yang berani mendekati anaknya baik untuk berteman maupun untuk melamar karena takut dengan pekerjaan Calon Arang. Sehingga Ratna Manggali kemudian jadi perbincangan orang-orang di Desa Girah sebagai sebuah aib dan dilabeli perawan 
tua. Kemudian ada Wedawati yang mengalami perubahan sikap atas posisi inferiornya di dalam keluarga. Pada awalnya Wedawati mengerjakan seluruh tugas-tugas domestik dengan rasa senang, kehidupannya menjadi contoh bagi perempuan-perempuan di lingkungannya. Tapi kemudian setelah ayahnya menikah lagi dan ia mendapatkan ibu tiri dan adik tiri Wedawati menerima perlakuan tidak menyenangkan dari ibu tirinya. Akhirnya Wedawati tak bisa menerima dominasi Ibu Tirinya dan pergi meninggalkan rumah memilih menjadi pertapa perempuan dan tidak menikah. Berbeda dengan tokoh perempuan lainnya, Ibu Tiri Wedawati yang khawatir dengan posisinya sebagai istri kedua dan ibu tiri kemudian mendominasi anak tirinya agar pergi dari rumah untuk mengamankan posisinya.

Selanjutnya adalah relasi atau hubungan perempuan dan laki-laki dalam CCA. Dari hasil pembahasan, relasi antara perempuan dan laki-laki menunjukkan bahwa kedudukan perempuan dalam CCA amatlah penting bahkan ditakuti oleh Raja. Relasi ini diwakilkan oleh Calon Arang. Raja yang menyadari bahwa Calon Arang amat sakti dan tak bisa dikalahakan oleh bala tentara mengkhawatirkan hal tersebut. Raja kemudian mencari jalan keluar untuk mengalahkan Calon Arang. Jatuhnya Calon Arang menjadi kera yang amat penting agar tidak ada kekuasaan yang lebih tinggi dari kekuasaan kerajaan seklaigus tidak ada yang lebih berkuasa dibanding Raja. Lalu strategi dibuat. Empu Baradah menggunakan relasi ibu dan anak antara Calon Arang dengan Ratna Manggali untuk mencari kelemahan Calon Arang. Ratna Manggali menjadi kunci untuk membongkar rahasia kekuatan Calon Arang. Siasat ini dilancarkan lewat pernikahan antara Ratna Manggali dengan Empu Baradah. Maka jelaslah bahwa Raja takut terhadap Calon Arang.
Ketiga bentuk dominasi patriarki tersebut akhirnya sangat mempengaruhi keputusan-keputusan perempuan dalam menentukan sikap terhadap kondisi inferior yang mereka alami. Calon Arang menggugat masyarakat dan pihak kerajaan dengan kekuatannya. Ratna Manggali secara tidak menerima kondisi dan perlakuan yang diterimanya dalam masyarakat. Kemudian ada Wedawati yang melakukan gugatan terhadap budaya lazim di lingkungannya dengan memutuskan untuk tidak menikah dan menjadi pertapa perempuan. Sedangkan Ibu Tiri Wedawati turut melanggengkan kondisi inferior perempuan untuk mengamankan posisinya dalam keluarga.

CCA menceritakan bagaimana
dominasi-dominasi yang dialami perempuan secara kompleks, mulai dari ranah domestik atau keluarga hingga di ruang-ruang publik ketika menjadi bagian dari masyarakat. CCA juga menunjukkan sikap dan keputusan perempuan. Sikap dan keputusan tersebut dapat dilihat dari gugatan yang dilakukan perempuan. Gugatan yang coba diperjuangkan perempuan dalam CCA meliputi: hak persamaan perempuan dan laki-laki, hak mengenai pekerjaan, hak pernikahan, hak memutuskan pilihan hidup. Peristiwaperistiwa yang terjadi dalam CCA menggambarkan perempua-perempuan yang menerima kondisi inferiornya hingga perempuan yang dengan berani menggugat masyarakat karena menempatkan posisi perempuan dalam subordiant sehingga membuat Raja ketakutan.

\section{DAFTAR PUSTAKA}

Endraswara, S. 2008. Metodologi Penelitian Sastra Epistemologi, Model, Teori, dan Aplikasi . Jakarta : PT. Buku Kita. 
Hellwing, Tineke. 2003. In The Shadow Of Change Citra Perempuan dalam Satra Indonesia. Jakarta Selatan: Desantara Utama.

Kutha Ratna, N. 2009. Teori, Metode, dan Teknik Penelitian Sastra. Yogyakarta: Pustaka Pelajar.

Moleong, Lexy. J. 2007. Metodologi penelitian Kualitatif. Bandung: PT Remaja Rosda Karya.

Sayuti, A. Suminto. 2000. Berkenalan dengan Prosa Fiksi. Yogyakarta: Gama Media.
Semi, M. Atar. 2012. Metode Penelitian Sastra. Bandung: Angkasa.

Suharto, \& Sugihastuti. 2015. Kritik Sastra Feminis Teori dan Aplikasinya. Yogyakarta: Pustaka Pelajar.

Thornman, Sue. 2010. Teori Feminis dan Cultural Studies . Yogyakarta: Jalasutra.

Toer, Pramoedya. A. 2015. Cerita Calon Arang. Jakarta: Lentera Dipantara.

Wellek, R., \& Warren, A. 1993. Teori Kesusteraan. Jakarta: PT. Gramedia. 